\title{
Molecular Analysis of Rifampicin Resistance Conferring Mutations in Mycobacterium tuberculosis
}

\author{
Fairuz H. Abdullah Tawgozy*
}

Bushra K. Qarasnji

Received 24/6/2019, Accepted 3/12/2019, Published 1/6/2020

This work is licensed under a Creative Commons Attribution 4.0 International License.

\begin{abstract}
:
Mycobacterium tuberculosis resistance to rifampicin is mainly mediated through mutations in the $r p o B$ gene. The effects of $r р о B$ mutations are relieved by secondary mutations in $r p o A$ or $r p o C$ genes. This study aims to identify mutations in rpoB, rpoA, and rpoC genes of Mycobacterium tuberculosis isolates and clarify their contribution to rifampicin resistance. Seventy isolates were identified by acid-fast bacilli smear, Genexpert assay, and growth on Lowenstein Jensen medium. Drug susceptibility, testing was performed by the proportional method. DNA extraction, PCR, and sequencing were accomplished for the entire rpoA, $r p o B$, and $r p o C$ genes. Twenty-three isolates $(32.85 \%)$ showed resistance to rifampicin by either proportion method or Genexpert assay. Sequence analysis of the rpoB gene revealed fourteen different mutation patterns. Inside the rifampicin resistance determining region (RRDR), codons: S531L, D516V were highly mutated with frequencies of $(21.73 \%, 17.39 \%)$ respectively. Outside the RRDR, there were nine different types of mutations, and M479L was the most prevalent one. Out of $23 \mathrm{RIF}$ resistant isolates, seven isolates (30.43\%) carried mutations in the rpoA gene, and twelve isolates $(52.17 \%)$ harbored a mutation in rpoC. Most of the mutations were identified for the first time in this study. The current study demonstrated that mutations in rpoB, rpoA, and rpoC contributed to RIF resistance in Mycobacterium tuberculosis and this new finding may be relevant to realize how compensatory mutations in the $r p o A$ and $r p o C$ genes restore the fitness cost caused by rifampin resistance-conferring mutations in rpoB.
\end{abstract}

Key words: Pulmonary tuberculosis, rpoA, rpoB, rpoC, RRDR, Tuberculosis.

\section{Introduction:}

Mycobacterium

tuberculosis (M. tuberculosis) causes tuberculosis (TB), which is the leading cause of death by infectious diseases worldwide, with an estimated 10.4 million new TB cases in 2016(1).

Iraq occupies $108^{\text {th }}$ rank globally and the $7^{\text {th }}$ position among the Eastern Mediterranean Region countries with high TB burden. About $3 \%$ of the total cases of TB exist in Iraq. In 2018, WHO estimated that there were 16,000 TB patients in Iraq and deaths due to TB exceeds 4000 annually. The estimated TB incidence rate was 42/100,000. According to the survey of 2014, levels of drug resistance in Iraq was low (1.1\%) (WHO). In overall, Iraq has a higher incidence rate of TB than all neighboring countries i.e. Syria, Jordan, Iran, Saudi Arabia and Turke (2).

Department of Biology, College of Science, Salahaddin University of Erbil, Erbil, Iraq.

*Corresponding author: fairuz.abdullah@su.edu.krd

"ORCID ID: https://orcid.org/0000-0001-6922-449X
This may be attributed to the instability, low socio-economic status and unsatisfactory treatment. The DOTS strategy has been adopted in Iraq since 1998, except for the three Iraqi Kurdistan provinces (Duhok, Erbil and Sulaimani), which has been implemented DOTS since 2001 (3).

Rifampicin, also called rifampicin an effective agent against different pathogens including mycobacteria and considers as an antituberculosis agent against susceptible strains as well as strains resistant to isoniazid or streptomycin (2). The antibacterial activity of rifampicin is due to its inhibition of transcription, by making specific contacts that involve the $\beta$-subunit of RNA polymerase (rpoB gene) and blocks growth of an RNA chain past 2 or 3 nucleotides (3). Elongating RNA polymerase is insensitive to rifampicin inhibition because RNA in the exit channel blocks rifampicin binding. Thus, runoff transcription continues after the addition of rifampicin (4).

Mutations in the rpoB gene, which encodes the $\beta$-subunit of RNA polymerase, lead to highlevel resistance to rifampicin, three clusters site 
mutation of $r p o B$ gene in rifampicin-resistant Escherichia coli strains were identified by Jin and Gross (5). Recently, several researchers have investigated nucleotide sequences of the cluster I and II regions of the $r p o B$ gene and exhibited mutations from rifampicin-resistant Mycobacterium tuberculosis strains (6) and (7). Moreover, several distinct regions in the genes rpoA and rpoC are potentially important regions in the compensatory evolution of rpoB (8).

The aims of this study to determine the epidemiological relevance of synonymous and nonsynonymous mutations in $r p o B, \quad r p o A$, and rрoC.

\section{Materials and Methods: \\ Bacterial Isolates (Mycobacterium tuberculosis)}

Four hundred and twenty-five sputum sample were received from patients at Chest and Respiratory Diseases Centre in Iraq-Erbil province from April 2016 to April 2017. Sputum smears were stained by ZN stain Kit (Atom Scientific, UK) (9), and further investigations performed by the growth rate, pigment production, colony morphology, niacin test, and nitrate reduction test.
The sputum samples were digested by Petroff's Method and cultured on LJ slant (10).

\section{Drug Susceptibility Testing}

Rifampicin susceptibility tests were carried out by Genexpert assay and proportion method. Genexpert assay was performed on sputum samples then isolates were cultured from sputum underwent susceptibility testing using the L-J proportion method according to the standard instructions Lowenstein Jensen medium, $0.25 \mu \mathrm{g} / \mathrm{ml}$ rifampicin, and $40 \mu \mathrm{g} / \mathrm{ml}$ isoniazid, the slants were incubated at $37^{\circ} \mathrm{C}$ and results were read at 28 days and up to 42 days, depending on control growth (11).

\section{Genomic DNA Extraction}

Chromosomal DNA was extracted by the lysozyme-proteinase $\mathrm{K}$ cetyl-trimethyl ammonium bromide (CTAB) method and stored at $4^{\circ} \mathrm{C}$ (12). The purity of DNA was checked with the NanoDropND-1000 spectrophotometer (NanoDrop Technologies).

\section{Polymerase Chain Reaction (PCR) and Primers}

Three primer sets were designed for target genes (rpoB, rpoA and $r p o C)$ as described in (Table 1) by NCBI primer designing tool (https://www.ncbi.nlm.nih.gov/tools/primer-blast/) and Clone Manager software was used for checking primers specificity.

Table 1. List of primers.

\begin{tabular}{|c|c|c|c|}
\hline Target Gene & Primer pair & Primer sequence $\left(5^{\prime}->3^{\prime}\right)$ & Product Size (bp) \\
\hline \multirow{4}{*}{ rроA } & 1 & F: TGTTCGGTTTCGGCGTAGTC & 1037 \\
\hline & & R: ATGCTGATCTCACAGCGCC & \\
\hline & 1 & F: TTGGCAGATTCCCGCCAGAG & 1098 \\
\hline & & R: GTGGTCGATGTCGTCGGTTTC & \\
\hline \multirow[t]{4}{*}{ rров } & 2 & F: GACGACATCGACCACTTC & 1038 \\
\hline & & R: CATCTCGCCGTCGTCAGTACAG & \\
\hline & 3 & F: TGTACTGACGACGGCGAGATG & 1165 \\
\hline & & R: CATCGGACTTGATGGTCAACAG & \\
\hline \multirow[t]{6}{*}{ rpoC } & 1 & F: CTCCGCATCGGTCTTGCTAC & 1008 \\
\hline & & R: GCGGTACAGGTCGTTCAAGT & \\
\hline & 2 & F: CTGTTCAAGCCGTTCGTGATG & 1122 \\
\hline & & R: CACCAGGCCCTTCATACCG & \\
\hline & 3 & F: GATCCGGAGATTGACGCTCTG & 1102 \\
\hline & & R: TGTAGCCGTAGTCGTCCAGC & \\
\hline
\end{tabular}

Target genes of $M$. tuberculosis were amplified by PCR using TC-412 thermal cycler (Techne-Japan) and amplicon sizes confirmed. 50 $\mu \mathrm{L}$ reaction mixture consisted of $25 \mu \mathrm{L}$ of master mix (GeneDirex/UK) $2 \mu \mathrm{L}$ of each primer set, 20 $\mu \mathrm{L}$ of $\mathrm{ddH} 2 \mathrm{O}$ and $3 \mu \mathrm{l} \mu \mathrm{L}(30 \mathrm{ng})$ of bacterial genomic DNA.

For rpoB, the PCR Amplification conditions included an initial denaturation step at $94^{\circ} \mathrm{C}$ for 2 minutes, followed by 35 cycles of $94^{\circ} \mathrm{C}$ for 1 minute, annealing at $65^{\circ} \mathrm{C}$ for 1 minute, and $72^{\circ} \mathrm{C}$ for 1 minute with a final extension at $72^{\circ} \mathrm{C}$ for 10 minutes. For both rpoA and $r p o C$ genes, PCR Amplification conditions comprised an initial denaturation step at $94^{\circ} \mathrm{C}$ for 1 minutes, followed by 35 cycles of $94^{\circ} \mathrm{C}$ for 1 minute, annealing at $58^{\circ} \mathrm{C}\left(\right.$ rpoA) and $59^{\circ} \mathrm{C}($ rpoC) for 1 minute, and $72^{\circ} \mathrm{C}$ for 45 seconds with a final extension at $72^{\circ} \mathrm{C}$ 
for 10 minutes. Each PCR products analysed by Agarose Gel Electrophoresis (13).

\section{Agarose Gel Electrophoresis}

Agarose gel electrophoresis was carried out using $1.5 \%$ agarose gels to analyze DNA according to its molecular weight mobility (13). $6 \mu \mathrm{L}$ from each PCR products were mixed with $2 \mu \mathrm{L}$ of loading dye and $4 \mu \mathrm{L}$ of SYBR ${ }^{\circledR}$ Safe $^{\mathrm{TM}}$ DNA Gel Stain (Life Technologies, UK) per $100 \mathrm{~mL}$ of agarose and run using $1 \times$ TAE buffer at $45 \mathrm{~V}$ for 15 min and then $90 \mathrm{~V}$ for $35-45 \mathrm{~min}$. The size of DNA fragments in the tested samples was evaluated using the GeneRuler $1 \mathrm{~kb}$ DNA ladder (QuickLoad®,UK). The bands were visualized using a UV lamp at $365 \mathrm{~nm}$, and images then captured by a Canon D100 (Canon Co., Japan).

Amplified PCR products were purified from the gel using (Gel Extraction Kit/Geneaid/Korea) then sent to Bioneer Corporation (South Korea), for sequencing using the Sanger sequencing method by ABI Genetic Analyzer 3130 (Applied Biosystems). Preliminary analysis of sequences and sequences alignment was performed using BioEdit. The sequences were compared with to wild type Mycobacterium tuberculosis sequence available at NCBI.

\section{Nucleotide Sequence Accession Numbers}

The nucleotide sequences of target genes mutation were deposited in the GeneBank database under the following accession numbers: MK874753- MK874779, and MK887216MK887231.

\section{Quality Control}

H37RV strain of Mycobacterium tuberculosis was selected as a control.

\section{Ethical Approval}

Ethical approval for this study is obtained from the ethical board of Chest and Respiratory Diseases Centre in Iraq-Erbil province.

\section{Results:}

Diagnosis and susceptibility of $M$. tuberculosis isolates to anti-TB drugs

Overall, four-hundred and twenty-five sputum samples were collected from suspected pulmonary TB patients, seventy isolates gave positive result by AFB smear microscopy, Genexpert assay, and grew on LJ medium as in (Table 2). The identity of the isolates was confirmed by cultural, morphological, and biochemical characteristics. All of the $M$. tuberculosis isolates were positive for niacin, nitrate reduction, nicotinamidase, pyrazinamide, and binding of neutral red tests. They were catalase negative at $25^{\circ} \mathrm{C}$ and $68^{\circ} \mathrm{C}(10)$.

Table 2. Two-by-two table comparing Genexpert MTB/RIF assay and sputum acid-fast bacilli smear.

\begin{tabular}{cccc}
\hline GeneXpert & AFB positive & $\begin{array}{c}\text { AFB } \\
\text { negative }\end{array}$ & Total \\
\hline MTB/Rif & & & \\
\hline MTB detected & 70 & 80 & 150 \\
\hline MTB not & 1 & 274 & 275 \\
\hline Detected & & & \\
\hline Total & 71 & 354 & 425 \\
\hline
\end{tabular}

Fifteen isolates were MDR-TB by Genexpert assay. The proportion method detected twenty-three $(28.57 \%)$ isolates resistant to rifampicin, all of which were isoniazid resistant, hence considered as MDR. Among MDR isolates by proportion method, twelve isolates $(70.5 \%)$ showed resistance to rifampicin by Genexpert assay and (3/47) rifampicin sensitive isolates by the proportion method considered as resistant by Genexpert assay as in Table 3.

Table 3. Two-by-two table comparing DST by Genexpert MTB/RIF assay and the proportion method on LJ medium.

\begin{tabular}{cccc}
\hline $\begin{array}{c}\text { GeneXpert } \\
\text { MTB/RIF }\end{array}$ & $\begin{array}{c}\text { Rif resist } \\
\text { on LJ }\end{array}$ & $\begin{array}{c}\text { Rif sensitive on } \\
\text { LJ }\end{array}$ & Total \\
\hline $\begin{array}{c}\text { Rif resist. } \\
\text { detected }\end{array}$ & 12 & 3 & 15 \\
\hline $\begin{array}{c}\text { Rif resist. not } \\
\text { detected }\end{array}$ & 11 & 47 & 55 \\
\hline Total & 23 & 50 & 70 \\
\hline
\end{tabular}

\section{Mutations in rpoB}

Amplified PCR products of $r p o B$ are shown in Fig. 1. Among 23 rifampicin resistant isolates, pre-RRDR contained four different mutation patterns, the most common one was M479L $(6 / 23,26.08 \%)$. Five mutation patterns were detected inside RRDR of $(15 / 23,65.21 \%)$ isolates. Five isolates $(5 / 23,21.73 \%)$ carried the S531L mutation along with M479L mutation in four isolates. The M479L mutation was found to coexist with the V475D mutation in one isolate. Four isolates (17.29\%) harbored the D516V mutation. Moreover, two isolates $(8.69 \%)$ possessed the S522L mutation associated with the T481I in the pre-RRDR of one isolate. Two isolates owned the H526R mutation. Isolates number $(1,13,17)$ were regarded as sensitive by Genexpert assay while they carried more than one mutation outside the RRDR. Among 47 RIF sensitive isolates, nine (19.14\%) harbored mutations outside the RRDR. No synonymous mutations exist within RRDR while 
one synonymous mutation was present in the preRRDR (P99P).

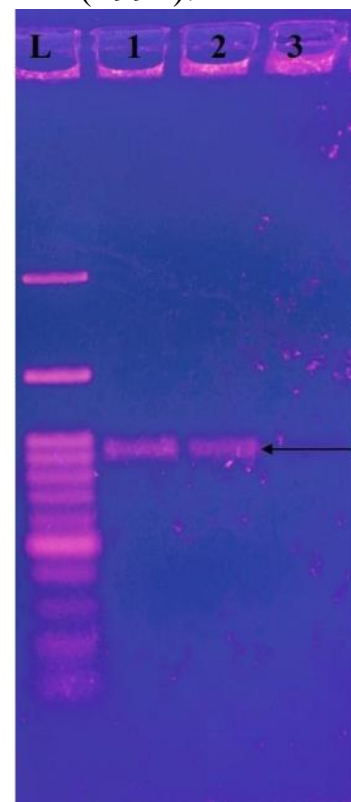

1037 bp

Figure 1. $\operatorname{rpoA}$ gene. Lane 1: Ladder, Lane 1: Positive control, Lane 2: Positive sample, Lane 3: Negative sample.

Mutations in rpoA and rpoC
Out of 23 RIF resistant isolates, seven isolates $(30.43 \%)$ carried nonsynonymous mutations in the rpoA gene as in Table 4. The mutations in the rpoA included Y59S, S87L, T187A，V183G，R182L，T332S, and the most prevalent one was $\mathrm{R} 182 \mathrm{~L}$. One isolate with the L194P mutation in rpoA gene has no mutation in $r p o B$ and $r p o C$.

Seven different types of mutations were identified in rpoC. Six of these mutations at codons (I281V，S260L，Q600E，G941A，D1120A, and A1201V) are reported for the first time in this study. The most common mutations were Q600E and S260L. No nonsynonymous mutations were detected in rpoA or rpoC.

\section{Data Availability Statement}

The [DNA Sequence data] used to support the findings of this study have been deposited in the [GenBank] under the following accession numbers: MK874753- MK874779, and MK887216MK887231.

Table 4. Frequency of mutations identified by sequencing in the $r p o A, r p o B, r p o C$ genes of Mycobacterium tuberculosis isolates.

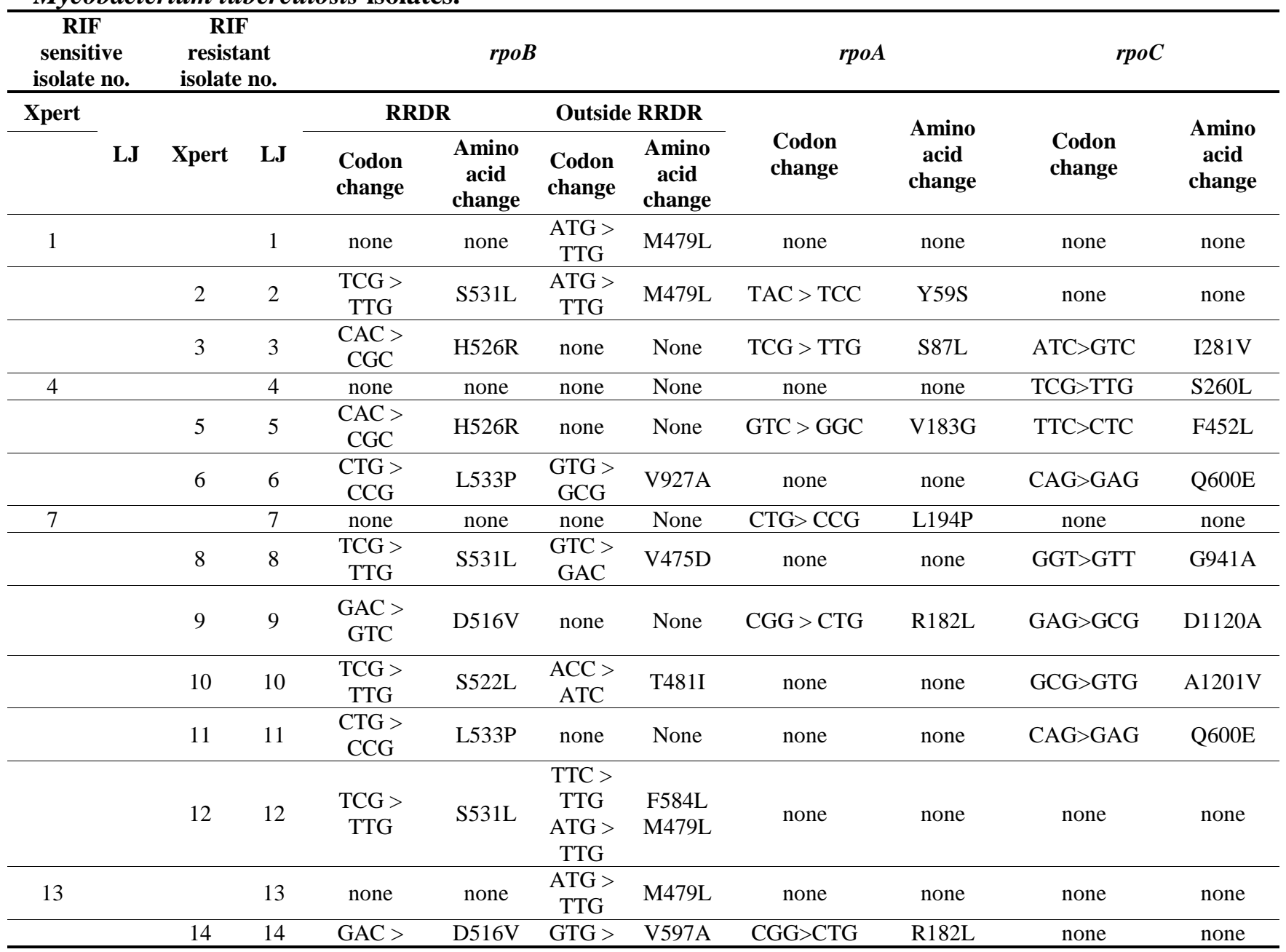




\begin{tabular}{|c|c|c|c|c|c|c|c|c|c|c|c|}
\hline & & & & GTC & & $\overline{\mathrm{GCG}}$ & & & & & \\
\hline & & 15 & 15 & $\begin{array}{c}\text { TCG > } \\
\text { TTG }\end{array}$ & S531L & $\begin{array}{c}\text { ATG > } \\
\text { TTG }\end{array}$ & M479L & none & none & none & none \\
\hline & & 16 & 16 & $\begin{array}{c}\text { TCG > } \\
\text { TTG }\end{array}$ & S531L & $\begin{array}{c}\text { ATG > } \\
\text { TTG }\end{array}$ & M479L & none & none & none & none \\
\hline \multirow[t]{4}{*}{17} & & & 17 & none & none & $\begin{array}{c}\mathrm{CTG}> \\
\mathrm{CCG}\end{array}$ & L943P & $\begin{array}{l}\mathrm{ACC}>\mathrm{GCC} \\
\mathrm{ACC}>\mathrm{AGC}\end{array}$ & $\begin{array}{l}\text { T187A } \\
\text { T332S }\end{array}$ & none & none \\
\hline & 18 & 18 & & $\begin{array}{c}\text { GAC > } \\
\text { GTC }\end{array}$ & D516V & $\begin{array}{c}\mathrm{CGT}> \\
\mathrm{CAT}\end{array}$ & R945H & none & none & none & none \\
\hline & 19 & 19 & & $\begin{array}{c}\text { GAC > } \\
\text { GTC }\end{array}$ & D516V & $\begin{array}{c}\text { GTG > } \\
\text { GCG }\end{array}$ & V691A & none & none & none & none \\
\hline & 20 & 20 & & $\begin{array}{c}\text { TCG > } \\
\text { TTG }\end{array}$ & S522L & none & None & none & none & $\begin{array}{l}\text { TCG }>\text { TTG } \\
\text { TTC }>\text { CTC }\end{array}$ & $\begin{array}{l}\text { S260L } \\
\text { F452L }\end{array}$ \\
\hline 21 & & & 21 & none & none & none & None & none & none & $\mathrm{CAG}>\mathrm{GAG}$ & Q600E \\
\hline 22 & & & 22 & none & none & none & None & none & none & GCG > GTG & A1201V \\
\hline 23 & & & 23 & none & none & none & None & none & none & GGT > GTT & G941A \\
\hline
\end{tabular}

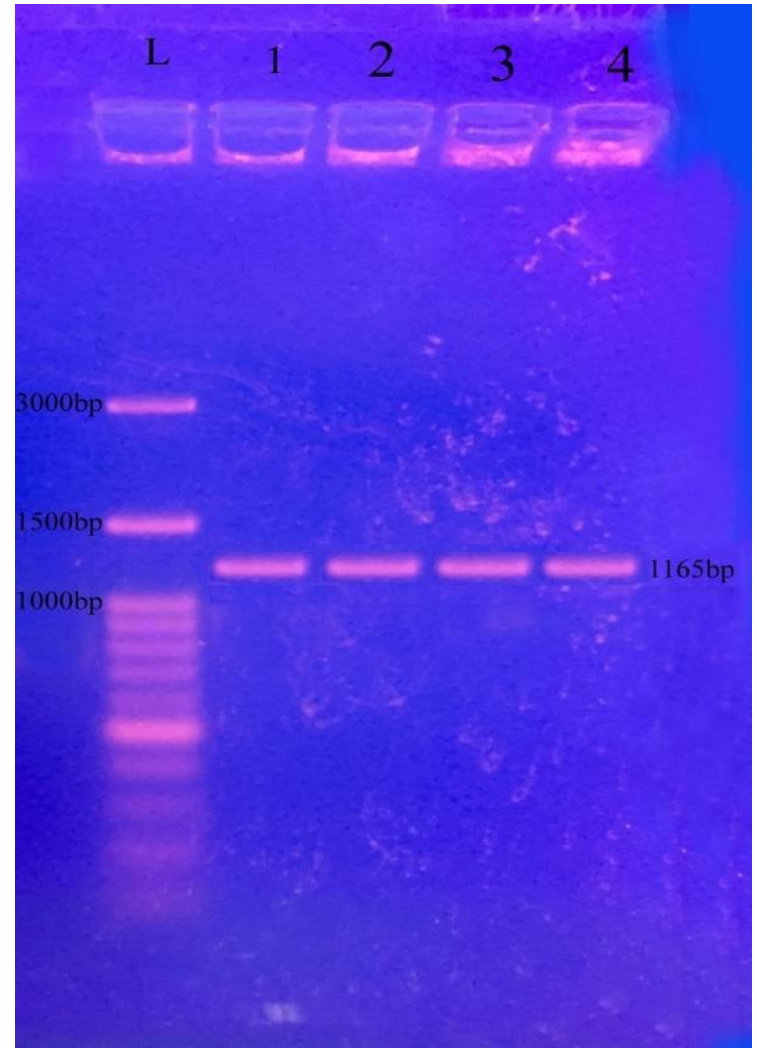

Figure 2. Agarose gel electrophoresis of amplified PCR products of the rpoB gene of $M$. tuberculosis.

Lane L: 100 bp DNA ladder

Lane 2-4: Amplified PCR products

\section{Discussion:}

To the best of our knowledge, this is the first study in Iraq which deals with rifampicin resistance and its associated genes using sequencing of the entire rpoB, rpoA, and rpoC genes. This study was undertaken on sputum samples collected from presumptive TB patients. Among four hundred and twenty-five presumptive TB patients, seventy were positive by AFB, LJ culture, and Genexpert assay. One of the currently available molecular techniques that simultaneously detects MTB and

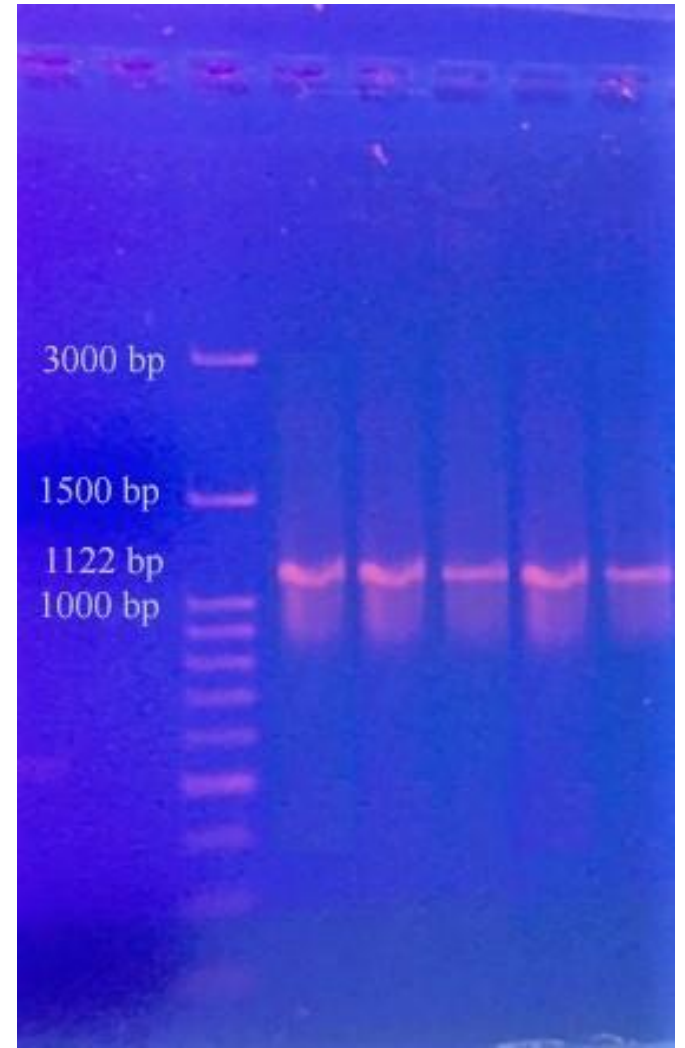

Figure 3. Agarose gel electrophoresis of amplified PCR products of the rpoC gene of $M$. tuberculosis.

Lane L: 100 bp DNA ladder

Lane 2-6: Amplified PCR products

RIF resistance-conferring mutations within RRDR of the rpoB gene is Genexpert assay (14). In our study, this technique detected MTB in (150/425, $35.29 \%)$ sputum samples. Among these, $(53.33 \%$, 80/150) were AFB negative. One AFB positive isolate was negative by Genexpert assay, which is attributed to the inability of this method to detect Mycobacterium bovis. This low level of detection with AFB is due to the presence of less than $105 / \mathrm{ml}$ bacteria in the sample (15). 
Multidrug resistance tuberculosis (MDRTB) denotes $M$. tuberculosis which is resistant to at least rifampicin and isoniazid (16). Annually, about half a million cases of MDR-TB recorded resulting in almost 0.25 million deaths per year. According to the survey of 2014, levels of drug resistance in Iraq was low (1.1\%) (17). Out of the 150 samples detected by Genexpert assay, rifampicin resistance was detected in $(15 / 150,10 \%)$. This result is higher than the studies of (18) and (19) which were (4.1\%), and $(6.9 \%)$ of their isolates that showed resistance to rifampicin. According to our results, there is a relatively high MDR cases $(23 / 70,32.85 \%)$. Improper treatment is an important reason for the increasing of MDR-TB.

Resistance to rifampicin is greatly associated with RRDR (codon 507-533) of the gene encoding RNA polymerase $B$, and several studies indicated the existence of novel mutations in $r p o B$ gene (20) and (16). Several studies have described the presence of common mutations in this region of $r p o B$ gene. In this study, we reported the presence of common and novel rрoB gene mutations in clinical M. tuberculosis isolates.

All culture positive isolates were investigated for mutations in the rpoB gene. Among 23 RIF resistant isolates, the entire rpoB gene sequence contains different mutation patterns. In our study, $(15 / 23,65.21 \%)$ isolates showed resistance to rifampicin and had a mutation in $81 \mathrm{bp}$ RRDR of rpoB gene. There were five mutation patterns within the RRDR, the most common of which are S531L (5/23, 21.73\%), and D516V (4/23, $17.29 \%)$. The less common mutations were L533P, S522L, H526R which have similar prevalence $(8.69 \%)$. This result is concordant with the study of (21) who reported common mutations at codons 531, 526 and 516 in Kuwait.

The most common mutation outside the RRDR was M479L found in $(6 / 23,26.08 \%)$ of the isolates. Although most of the studies revealed single mutation in $r p o B$ gene, we found double mutation in $(9 / 23,39.13 \%)$ isolates and triple mutation in one isolate. The current results are similar to the studies of $(22,23)$ and even triple mutation as reported by (22).

In addition to common mutations within RRDRD, new non-synonymous mutations were identified in our study including Met479 Leu, Val475Asp, Thr481Ile, Phe584Leu, Val 597Ala, Val691Ala, Val927Ala, Leu943Pro, and one synonymous mutation Pro99Pro. In addition to the previously reported mutations, there are newly identified mutations in the current study. The increase in mutations probably due to the ability of $M$. tuberculosis to fit itself with anti-tubercular drugs through more than one mutations in RIF resistance-related genes.

Brandis et al., (2012) (24) declared that compensatory mutations in the genes rpoA and rpoC relieve the fitness cost caused by rifampicin resistance-conferring mutations in rpoB. Another study (Comas et al.,2011) (25) proposed that secondary mutations in the rpoA or rpoC gene could alleviate the fitness cost incurred by rpoB mutations, especially those in the RRDR. We investigated the rpoC mutation patterns in drugresistant and susceptible $M$. tuberculosis isolates. Seven different types of mutations were identified, six of which are reported for the first time in this study. Mutation at codons 600 and 260 were the most common mutations (7/24, 29.2\%).

Among 23 RIF resistant isolates analyzed for mutations in the rpoA gene, $(6 / 23,26.08 \%)$ harbored nonsynonymous mutations. The most prevalent one is $\mathrm{R} 182 \mathrm{~L}$. There is no nonsynonymous mutation in rpoA.

\section{Conclusions:}

This study provided the first investigation that mutations in rpoB, rpoA, and rpoC contribute to RIF resistance in M. tuberculosis. Also, there are mutations outside the RRDR of $r p o B$ which provided resistance to rifampicin. Five mutation patterns are detected inside the RRDR of $r p o B$; the most common is S531L mutation. Although there are no synonymous mutations within the RRDR, there is one synonymous mutation (P99P) outside the RRDR.

The number of mutation sites in both rpoA and $r p o C$ is equal. There are seven nonsynonymous mutations in the rpoA gene, and the most prevalent one is R182L. The most common mutations in rpoC are Q600E and S260L. No synonymous mutations are detected in rpoA or rpoC. These new findings may be relevant to realize how compensatory mutations in the rpoA and $r p o C$ genes restore the fitness cost caused by rifampin resistanceconferring mutations in rpoB.

\section{Acknowledgments}

We would like to express our gratitude and appreciation to the staff of Biology Department/ College of Science/ Salahaddin University-Erbil and Chest and Respiratory Diseases Center/ Ministry of Health in Erbil city for their help throughout the study period. We value the participation of the suspected TB patients and thank them for their assistance.

\section{Authors' declaration:}

- Conflicts of Interest: None. 
- We hereby confirm that all the Figures and Tables in the manuscript are mine ours. Besides, the Figures and images, which are not mine ours, have been given the permission for republication attached with the manuscript.

- Ethical Clearance: The project was approved by the local ethical committee in Salahaddin University.

\section{References}

1. Gilpin C, Korobitsyn A, Migliori GB, Raviglione MC, Weyer K. The World Health Organization standards for tuberculosis care and management. Eur Respir J; 2018. Available from: DOI: https://doi.org/10.1183/13993003.00098-2018.

2. Maldhure SR, Munje RP, Zodpey SP, Fuladi AS and Pillai AP. Influence of initial drug resistance on response to short course chemotherapy of pulmonary tuberculosis. Lung India. 1997;15(4):181-85. Available from: https://www.researchgate.net/publication/315782632 _Influence_of_initial_drug_resistance_on_response_t o_short_course_chemotherapy_of_pulmonary_tuberc ulosis. DOI:

3. Johnston DE, McClure WR. Abortive initiation of in vitro RNA synthesis on bacteriophage $\lambda$ DNA. Cold Spring Harbor Monograph Archive. 1976;6:413-28. Available from: DOI:

4. Campbell EA, Korzheva N, Mustaev A, Murakami K, Nair S, Goldfarb A, et al. Structural mechanism for rifampicin inhibition of bacterial RNA polymerase. Cell. 2001;104(6):901-12. Available from: https://www.sciencedirect.com/science/article/pii/S00 92867401002860

DOI: https://doi.org/10.1016/S0092-8674(01)00286-0

5. Jin DJ, Gross CA. Mapping and sequencing of mutations in the Escherichia coli rpoB gene that lead to rifampicin resistance. Journal of molecular biology. 1988;202(1):45-58. Available from: https://www.sciencedirect.com/science/article/abs/pii/ 0022283688905177 https://doi.org/10.1016/0022-2836(88)90517-7.

6. Kapur V, Li L-L, Iordanescu S, Hamrick MR, Wanger A, Kreiswirth BN, et al. Characterization by automated DNA sequencing of mutations in the gene (rpoB) encoding the RNA polymerase beta subunit in rifampin-resistant Mycobacterium tuberculosis strains from New York City and Texas. J Clin Microbiol. 1994;32(4):1095-8. Available from: https://www.ncbi.nlm.nih.gov/pmc/articles/PMC2671 94/ DOI:

7. Taniguchi H, Aramaki H, Nikaido Y, Mizuguchi Y, Nakamura M, Koga T, et al. Rifampicin resistance and mutation of the rpoB gene in Mycobacterium tuberculosis. FEMS Microbiol Lett.. 1996;144(1): 103-8. Available from: https://www.ncbi.nlm.nih.gov/pubmed/8870258

DOI:

8. De Vos M, Müller B, Borrell S, Black P, Van Helden $\mathrm{P}$, Warren R, et al. Putative compensatory mutations in the rpoC gene of rifampin-resistant Mycobacterium tuberculosis are associated with ongoing transmission. Antimicrob Agents Chemother. 2013;57(2):827-32. Available from: https://www.ncbi.nlm.nih.gov/pmc/articles/PMC3553 $702 /$ DOI: https://dx.doi.org/10.1128\%2FAAC.01541-12

9. Sharma SK, Kohli M, Yadav RN, Chaubey J, Bhasin $\mathrm{D}$, Sreenivas V, et al. Evaluating the diagnostic accuracy of Xpert MTB/RIF assay in pulmonary tuberculosis. PloS one. 2015;10(10):e0141011. Available from: https://www.ncbi.nlm.nih.gov/pmc/articles/PMC4619 889/ DOI: https://dx.doi.org/10.1371\%2Fjournal.pone.0141011.

10. Ichhpujani RBRL. Essentials of Medical Microbiology Fourth Edition ed: JAYPEE BROTHERS MEDICAL PUBLISHERS; 2008. 517 p.

11. Banu S, Rahman SM, Khan MSR, Ferdous SS, Ahmed S, Gratz J, et al. Discordance across several methods for drug susceptibility testing of drugresistant Mycobacterium tuberculosis isolates in a single laboratory. J. Clin. Microbiol.. 2014;52(1):15663. Available from: https://www.ncbi.nlm.nih.gov/pmc/articles/PMC3911 413/ DOI: https://dx.doi.org/10.1128\%2FJCM.0237813

12. Jagielski $\mathrm{T}$, Ignatowska $\mathrm{H}$, Bakuła $\mathrm{Z}$, Dziewit $\mathrm{\ell}$, Napiórkowska A, Augustynowicz-Kopeć E, et al. Screening for streptomycin resistance-conferring mutations in Mycobacterium tuberculosis clinical isolates from Poland. PLoS One. 2014;9(6):e100078.

13. Green MR, Sambrook J. Molecular cloning. A Laboratory Manual. 4th. New York: Cold Spring Harbor Laboratory Press. 2012.

14. Suzana S, Ninan MM, Gowri M, Venkatesh K, Rupali P, Michael JS. Xpert MTB/Rif for the diagnosis of extrapulmonary tuberculosis-an experience from a tertiary care centre in South India. Trop Med Int Health.. 2016;21(3):385-92. Available from: https://onlinelibrary.wiley.com/doi/full/10.1111/tmi.1 2655 DOI: https://doi.org/10.1111/tmi.12655

15. Bhatt CP, Timalsina B, Kutu B, Pradhan R, Maharjan B, Shrestha B. A Comparision of Laboratory Diagnostic Methods of Tuberculosis and Aetiology of Suspected Cases of Pulmonary Tuberculosis. SAARC Journal of Tuberculosis, Lung Diseases and HIV/AIDS. 2015;11(2):1-6. Available from: https://www.researchgate.net/publication/276100723 _A_Comparision_of_Laboratory_Diagnostic_Method s_of_Tuberculosis_and_Aetiology_of_Suspected_Ca ses_of_Pulmonary_Tuberculosis

DOI: 10.3126/saarctb.v11i2.12427

16. Zhao L-L, Chen Y, Liu H-C, Xia Q, Wu X-C, Sun Q, et al. Molecular characterization of multidrugresistant Mycobacterium tuberculosis isolates from China. Antimicrob Agents Chemother. 2014;58(4):1997-2005. Available from: https://www.ncbi.nlm.nih.gov/pmc/articles/PMC4023 $728 /$ DOI: https://dx.doi.org/10.1128\%2FAAC.01792-13 
17. WHO. [Available from: http://www.emro.who.int/irq/programmes/tuberculosi s.html.

18. Lombardi G, Di Gregori V, Girometti N, Tadolini M, Bisognin F, Dal Monte P. Diagnosis of smearnegative tuberculosis is greatly improved by Xpert MTB/RIF. PloS one. 2017;12(4):e0176186. Available from: DOI:

19. Okonkwo R, Onwunzo M, Chukwuka C, Ele P, Anyabolu A, Onwurah C, et al. The Use of the Gene Xpert Mycobacterium tuberculosis/Rifampicin (MTB/Rif) Assay in Detection of Multi-Drug Resistant Tuberculosis (MDRTB) in Nnamdi Azikiwe University Teaching Hospital, Nnewi, Nigeria. J HIV Retrovirus. 2017;3:1. Available from: DOI:

20. Prasad R, Gupta N, Banka A. Multidrug-resistant tuberculosis/rifampicin-resistant tuberculosis: Principles of management. Lung India: official organ of Indian Chest Society. 2018;35(1):78. Available from: DOI:

21. Al-Mutairi NM, Ahmad S, Mokaddas E, Eldeen HS, Joseph S. Occurrence of disputed rpoB mutations among Mycobacterium tuberculosis isolates phenotypically susceptible to rifampicin in a country with a low incidence of multidrug-resistant tuberculosis. BMC infectious diseases. 2019;19(1):3. Available from: DOI:

22. Pozzi G, Meloni M, Iona E, Orru G, Thoresen O, Ricci $M$, et al. rpoB mutations in multidrug-resistant strains of Mycobacterium tuberculosis isolated in Italy. Journal of clinical microbiology. 1999;37(4):1197-9. Available from: DOI:

23. Takawira FT, Mandishora RSD, Dhlamini Z, Munemo E, Stray-Pedersen B. Mutations in $r p o B$ and $k a t G$ genes of multidrug resistant mycobacterium tuberculosis undetectable using genotyping diagnostic methods. Pan African Medical Journal. 2017;27(1). Available from: DOI:

24. Brandis G, Wrande M, Liljas L, Hughes D. Fitnesscompensatory mutations in rifampicin-resistant RNA polymerase. Mol microbiol. 2012;85(1):142-51. Available from: https://www.ncbi.nlm.nih.gov/pubmed/22646234. DOI: https://doi.org/10.1111/j.13652958.2012.08099.x

25. Comas I, Borrell S, Roetzer A, Rose G, Malla B, Kato-Maeda M, et al. Whole-genome sequencing of rifampicin-resistant Mycobacterium tuberculosis strains identifies compensatory mutations in RNA polymerase genes. Nat Genet. 2012;44(1):106. Available from: DOI: https://dx.doi.org/10.1038/ng.1038.

$$
\begin{aligned}
& \text { التحليل الجزيئي لمقاومة الريفامبيسين يمنح طفرات في مرض السل المتفطرات }
\end{aligned}
$$

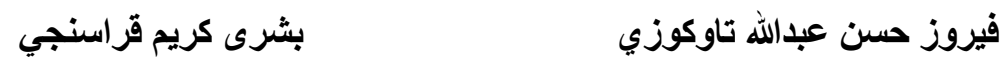

$$
\begin{aligned}
& \text { قسم علوم الحياة، كلية العلوم، جامعة صلاح الدين، أربيل، العر اق. }
\end{aligned}
$$

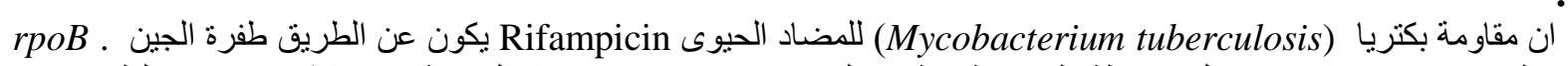

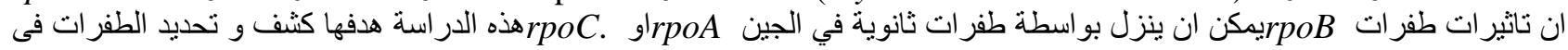

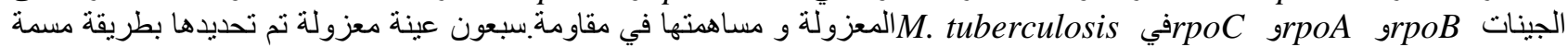

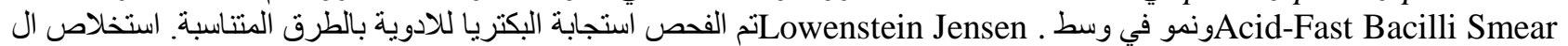

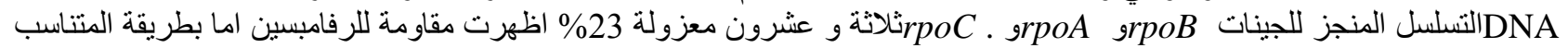

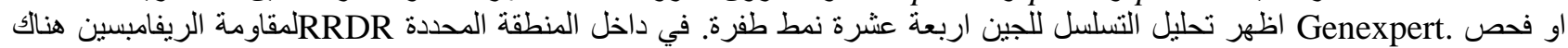

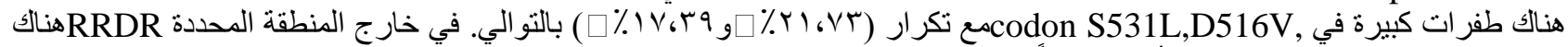

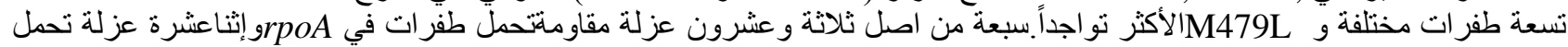

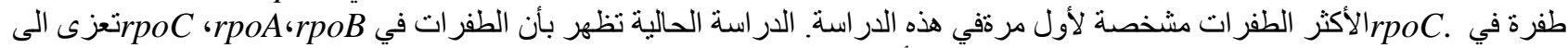

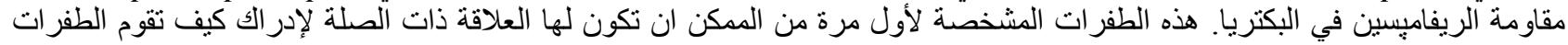

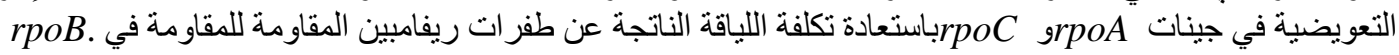

$$
\text { الكلمات المفتاحية: السل الرئوي، جين rpoA، جين rpoB، جين rpoC، منطقة RRDR ، السل. }
$$

